UDK 632.954:632.983

Naučni rad-Scientific paper

\title{
Critical time for weed removal in dicamba tolerant soybean as influenced by pre emergence herbicides
}

\author{
Darko Jovanović ${ }^{1}$, Ivan Cuvaca ${ }^{2}$, Jon Scott ${ }^{2}$, Stevan Knežević ${ }^{2}$ \\ ${ }^{1}$ University of Belgrade, Faculty of Agriculture, Belgrade, Serbia \\ ${ }^{2}$ Departments of Agronomy and Horticulture, University of Nebraska-Lincoln, NE, USA \\ e-mail: darkocovdinac@gmail.com
}

\section{SUMMARY}

Field experiment was conducted in 2019 at Haskell Agriculture Laboratory, Concord, NE, USA. Goal of the study was to test the influence of PRE-EM herbicides on the Critical Time for Weed Removal (CTWR) in dicamba-tolerant soybean. The study was arranged in a split-plot design which consisted of four herbicide regimes as main plot treatments and seven weed removal timings as subplot treatments, with four replications. The herbicide regimes included: (1) no PRE and glyphosate, (2) acetochlor and dicamba as PRE and glyphosate as POST, (3) acetochlor and dicamba as PRE and glyphosate and dicamba as POST, and (4) acetochlor and fomesafen as PRE and acetochlor, glyphosate and dicamba as POST. The five weed removal times included the V1, V3, V6, R2 and R5, and there were also weedy and weed-free season long plots. By utilizing herbicide regimes, the CTWR was delayed to 632 GDD (until V4 soybean growth stage, 28 days after emergence) for acetochlor and dicamba as PRE and glyphosate as POST, 861 GDD (until V6 soybean growth stage, 32 days after emergence) for acetochlor and dicamba as PRE and glyphosate and dicamba as POST, and 1060 GDD (until R1 soybean growth stage, 42 days after emergence) for acetochlor and fomesafen as PRE and acetochlor, glyphosate and dicamba as POST. Keywords: PRE-EM herbicides, Critical Time for Weed Removal, Glyphosate resistance, Integrated Weed Management.

\section{INTRODUCTION}

Glyphosate is a nonselective, POST-emergence herbicide that has been in use for almost half a century (Duke and Powles, 2008). The commercial availability of glyphosate-resistant 
(GR) soybean (Glycine max L.), as well as GR corn (Zea mays L.), GR canola (Brassica napus L.), GR alfalfa (Medicago sativa L.), and GR sugar beet (Beta vulgaris L.) has led to a drastic increase in the use of glyphosate over the last 20 years (Heap and Duke, 2018), especially in the United States. Since their introduction, U.S. farmers have planted millions of acres of Roundup Ready crops, especially corn and soybean (Boerboom and Owen, 2006).

As a result, the use of PRE-herbicides has decreased, and more pressure was placed on Roundup (a.i. glyphosate). This overreliance on glyphosate has led to many weed species becoming resistant to glyphosate (Heap, 2020).

In response, growers started combining glyphosate-based products with other herbicides with different modes of action, as well as using more PRE-herbicides. PRE-herbicides are soil apllied herbicides that can suppress weeds for 30-60 days after application However, how long the field stays free of weeds depends on several factors including: precipitation, herbicide type, its persistence and soil weed seed bank. These factors can influence the Critical Period for Weed Control (CPWC).

In brief, the CPWC is a period in the crop growth cycle during which weeds must be controlled to prevent yield losses (Knezevic et al., 2002). During this period the crop should be kept weed-free. The duration of this period for a particular crop can be influenced by several factors, including weather conditions (e.g. rainfall), weed species and their densities, as well as the type of herbicide.

In general, the CPWC has a beginning and an end. Weeds that emerge before or after the CPWC may not represent a threat for the crop yields. For example, it was suggested that corn should be kept weed-free from the $3^{\text {rd }}$ to the $10^{\text {th }}$ leaf stage (V3-V10) (Hall et al., 1992), and soybean from approximately the second trifoliate (V2) to the beginning pod (R3) (Van Acker et al., 1993; Mulugeta and Boerboom, 2000).

There are two components of CPWC, the critical time for weed removal (CTWR) and critical weed free period (CWFP). The CTWR is the maximum amount of time that the early season weed competition can be tolerated by the crop before the crop suffers irreversible yield reductions. This component is also commonly referred to as the "beginning" of the CPWC. The CWFP is the minimum weed-free period required from the time of the crop planting required to prevent unacceptable yield losses (Knezevic and Datta, 2015). This component determines the "end" of the CPWC. Both components are required to determine the CPWC of a particular crop (Knezevic et al., 2002). According to Knezevic and Datta (2015), weed control before and after the CPWC does not significantly contribute to the conservation of the crop yield potential.

The beginning of the CPWC is marked by $5 \%$ as an acceptable yield loss (AYL). It also marks the CTWR - Critical Growth Stage $\mathrm{x}_{\mathrm{x}}\left(\mathrm{CGS}_{\mathrm{x}}\right)$. CGS - Critical Growth Stage $_{\mathrm{y}}$ represents the end of the CPWC and is the CWFP. Essentially, the area between the CGSx and the CGSy is the period in the crop growth cycle when weeds must be controlled. Knowledge of the CPWC can help reduce herbicide use by allowing farmers to control weeds with one well-timed herbicide application, instead of two (Clayton et al., 2002). The goal of the study was to test the influence of PRE-EM herbicides on CTWR in dicamba-tolerant soybean. 


\section{MATERIAL AND METHODS}

Experimental site. A field trial was conducted in 2019 at the Haskell Agricultural Laboratory (HAL), Concord $\left(42.37^{\circ} \mathrm{N}, 96.95^{\circ} \mathrm{W}\right)$, NE, USA as part of the internship project of the first author. Soil at the site was Nora silty clay loam, with a slightly acidic $\mathrm{pH}$ of $5.4,5 \%$ organic matter content and $29.9 \mathrm{mEq} / 100 \mathrm{~g}$ cation exchange capacity.

The field was disked, cultivated and planted on June $5^{\text {th }}$, utilizing John Deere ${ }^{\circledast}$ finger pickup planter. The plots were $7.6 \mathrm{~m}$ by $3 \mathrm{~m}$ each, with four rows of soybean planted at the density of 370,127 seeds/hectare and $76 \mathrm{~cm}$ apart. Dicamba Tolerant Soybean variety planted was Asgrow AG27X8. Rainfall varied from month to month throughout the growing season (Figure 1).

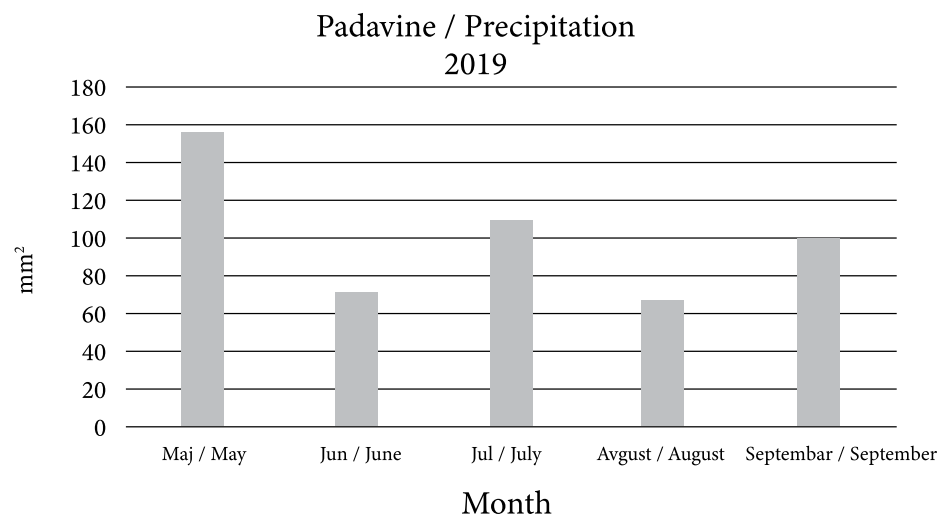

Figure 1. Precipitation $\left(\mathrm{mm} / \mathrm{m}^{2}\right)$ by months at Haskell Ag Lab, Concord, NE, USA in 2019

Grafik 1. Mesečene sume padavina za Haskell, Concord, NE, USA u 2019. godini

Experimental design. The experiment was established in a split-plot design which consisted of four herbicide regimes as main plot treatments and seven weed removal timings as subplot treatments, with four replications. The presence of PRE herbicide (PRE) or its absence (no PRE) represented the main plots. Specifically, the main plots consisted of 4 different herbicide regimes, with 3 PRE herbicides (No PRE, Warrant and Warrant ultra) and 3 POST (Roundup PowerMax, XtendiMax and Warrant) herbicides described as follows:

1. NP - No PRE + Roundup PowerMax (a.i. glyphosate);

2. WXR - Warrant (a.i. acetochlor) + XtendiMax (a.i. dicamba) + Roundup PowerMax (a.i. glyphosate);

3. WXRX - Warrant (a.i. acetochlor) + XtendiMax (a.i. dicamba) + Roundup PowerMax (a.i. glyphosate) + XtendiMax (a.i. dicamba);

4. WuWRX - Warrant ultra (a.i. acetochlor + a.i. fomesafen) + Warrant (a.i. acetochlor) Roundup PowerMax (a.i. glyphosate) + XtendiMax (a.i. dicamba) + Roundup PowerMax (a.i. glyphosate). 
The sub-plots consisted of 5 different weed removal times:

1. First trifoliate (V1),

2. Third trifoliate (V3),

3. Sixth trifoliate (V6),

4. Full flowering (R2),

5. Beginning seed (R5), and

6. Weed-free and weedy season long treatments.

After the specified removal times, main plot treatments No PRE-EM and one Warrant (a.i. acetochlor) + XtendiMax (a.i. dicamba) following Roundup PowerMAX (a.i. glyphosate) POST were hand-hoed and kept weed-free throughout the rest of the season. The second Warrant (a.i. acetochlor) + XtendiMAX (a.i. dicamba) and Warrant ultra (a.i. acetochlor + a.i. fomesafen) main plot treatments were not hand-hoed because they were followed by POST application of Roundup PowerMAX (a.i. glyphosate) + XtendiMax (a.i. dicamba) in and Roundup PowerMAX (a.i. glyphosate) + XtendiMax (dicamba) + Warrant (a.i. acetochlor), respectively. Herbicides were applied using a $\mathrm{CO}_{2}$-pressurized backpack sprayer with TeeJet ${ }^{\oplus}$ flat-fan nozzles (Spraying Systems, Wheaton, IL 60187), spaced at $56 \mathrm{~cm}$ and calibrated to deliver $140 \mathrm{~L} \mathrm{ha}^{-1}$ of aqueous solution. PRE herbicides were applied with TeeJet ${ }^{\oplus}$ AIXR 110015. POST herbicides were applied with TeeJet ${ }^{\oplus}$ TTI 80015 or TeeJet $^{\oplus}$ XRC 8002 nozzles.

Data collection and analysis. Daily minimum and maximum temperatures were recorded and used to calculate soybean growing degree days (GDD) with the following equation:

$$
\mathrm{GDD}=\Sigma\left(\mathrm{T}_{\max }+\mathrm{T}_{\min } / 2\right)-\mathrm{T}_{\text {base }}
$$

where $\mathrm{T}_{\max }$ and $\mathrm{T}_{\min }$ are the maximum and minimum daily air temperatures, and $\mathrm{T}_{\text {base }}$ is the base temperature for soybean growth. Temperature of $10^{\circ} \mathrm{C}$ was used as $\mathrm{T}_{\text {base }}$.

Weed density and composition was documented for each plot and weed species recorded prior to weed removal. Weed counts were conducted within $0.50 \mathrm{~m}^{2}$ quadrats placed in the middle of each plot. The two middle rows were harvested using an Almaco SP40 combine, and the yield was recorded for each plot. Data were subjected to dose response analysis using the $d r c$ package in $R$ version 3.4.1 (Knezevic et al., 2007).

\section{RESULTS AND DISCUSSION}

Weed density and weed composition. Most weeds emerged 2 days before soybean. The most common weed species were Green foxtail (Setaria viridis L.), Common waterhemp (Amaranthus tuberculatus L.), Velvetleaf (Abutilon teophrasti L.) and Common lambsquarter (Chenopodium album L.) (Table 1). Green foxtail was the predominant species compared to broadleaf weeds, which accounted for more than half of the weed population with a density of 220 plants per square meter (Table 1 ). 
Table 1. Average weed density and species composition

Tabela 1. Sastav vrsta i prosečna brojnost korova

\begin{tabular}{lccc}
\hline $\begin{array}{l}\text { Weed species } \\
\text { Korovske vrste }\end{array}$ & $\begin{array}{c}\text { Type } \\
\text { Tip korova }\end{array}$ & $\begin{array}{c}\text { Density }\left(\mathbf{m}^{2}\right) \\
\text { Brojnost }\left(\mathbf{m}^{2}\right)\end{array}$ & $\begin{array}{c}\text { Weed population (\%) } \\
\text { Korovska populacija (\%) }\end{array}$ \\
\hline Setaria viridis $\mathrm{L}$. & Grass & 220 & 54 \\
Amaranthus tuberculatus $\mathrm{L}$. & Broadleaf & 156 & 38 \\
Abuthilon theophrasti $\mathrm{L}$. & Broadleaf & 28 & 7 \\
Chenopodium album $\mathrm{L}$. & Broadleaf & 4 & 1 \\
\hline
\end{tabular}

Furthermore, Green foxtail accounted for $54 \%$ of the overall weed population, whereas the other three weed species together accounted for only $46 \%$.

Yield losses. Significant yield losses varied among the herbicide programs. The highest losses of almost $60 \%$ were recorded in plots without PRE herbicides. This is a result of weedcrop competition during the early and mid-crop growth stages. In plots where PRE herbicides were applied, the yield losses were lower. For example, maximum yield losses of $19 \%$ were in WXR weedy season long, compared to $18 \%$ weedy season long in WXRX and 32\% in weedy season long WuWRX. The most significant difference in yield losses was between No PRE and WuWRX herbicide regimes (Figure 2).

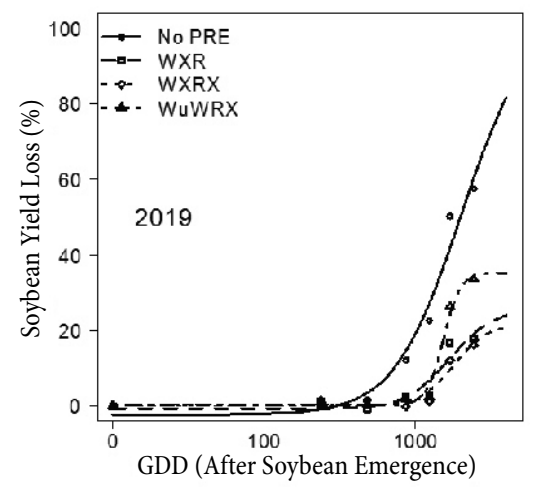

Figure 2. Soybean yield loss (\%) with and without PRE herbicides

Grafik 2. Gubitak prinosa soje (\%) u varijanti sa i bez pre-em primene herbicida

Beginning of CPWC in Soybean. There were differences in CTWR between herbicide regimes. The CTWR started 16, 28, 32 DAE and 42 DAE, respectively for the NP, WXR, WXRX and WuWRX. The difference between No PRE and WuWRX in particular is not only significant, but also the most pronounced. The delay of CTWR between these two treatments was 26 days (Table 2).

By delaying CTWR for 26 days until R1 growth stage, soybeans have enough time to grow, close the canopy and cover the soil ground, thus preventing new weed flashes during the 
reproductive stages when weed control is more challenging. The difference between No PRE and both herbicide regimes where acetochlor and dicamba (short residual activity) were applied as PRE (WXR and WXRX) was almost 14 days (12 for WXR and 16 for WXRX) and presents a good example of how PRE herbicides can delay the CTWR.

Table 2. Critical Time for Weed Removal (CTWR) based on the 5\% yield loss

Tabela 2. Kritično vreme suzbijanja korova (KVSK) za gubitak prinosa od 5\%

\begin{tabular}{lccc}
\hline $\begin{array}{l}\text { Herbicide treatments } \\
\text { Herbicidni tretmani }\end{array}$ & $\begin{array}{c}\text { GDD }(\text { SE) } \\
\text { Sume efektivnih temperatura }\end{array}$ & $\begin{array}{c}\text { DAE } \\
\text { Dani posle nicanja }\end{array}$ & $\begin{array}{c}\text { Soybean Stage } \\
\text { Faza razvoja soje }\end{array}$ \\
\hline NP & $450(6)$ & 16 & V2 \\
WXR & $632(80)$ & 28 & V4 \\
WXRX & $861(104)$ & 32 & V6 \\
WuWRX & $1060(33)$ & 42 & R1 \\
\hline
\end{tabular}

GDD - growing degree days, SE - standard error, DAE - Days after soybean emergence

NP - No PRE + Roundup PowerMax (a.i. glyphosate);

WXR - Warrant (a.i. acetochlor) + XtendiMax (a.i. dicamba) + Roundup PowerMax (a.i. glyphosate);

WXRX - Warrant (a.i. acetochlor) + XtendiMax (a.i. dicamba) + Roundup PowerMax (a.i. glyphosate) + XtendiMax (a.i. dicamba);

WuWRX - Warrant ultra (a.i. acetochlor + a.i. fomesafen) + Warrant (a.i. acetochlor) Roundup PowerMax (a.i. glyphosate) +

XtendiMax (a.i. dicamba) + Roundup PowerMax (a.i. glyphosate).

With the beginning of CPWC the weed presence starts to have and impact on the yield components.

\section{DISCUSSION}

It is certain tha the use of PRE-emergence herbicides can delay the CTWR in soybean. For example, Knezevic et al (2019) have reported that the beginning of the CTWR is 14 DAE, without PRE herbicide, while the application of saflufenacil + imazethapyr + pyroxasulfone or sulfentrazone + imazethapyr delays the CTWR to $28 \mathrm{DAE}$ (V4 soybean growth stage) or $35 \mathrm{DAE}$ (V5 soybean growth stage), thus indicating that the CTWR was delayed by 14 and 21 days, respectively. In our study different herbicides delayed the CTWR similarly. For example, the CTWR started 16 DAE (at V2 soybean growth stage), 28 DAE (V4 soybean growth stage), $32 \mathrm{DAE}$ (V6 soybean growth stage), and $42 \mathrm{DAE}$ (R1 soybean growth stage), respectively for the following herbicide regimes NP, WXR, WXRX, and WuWRX.

Selecting the best PRE-herbicide for a particular field is very important. Ideally, the right PRE herbicide should control most weeds that are present in the field including the resistant biotypes. However, this would require combining two or more effective modes of action. Each field is different and, therefore, should be treated differently. PRE-emergence herbicides are even more important when we consider weed resistance, especially to glyphosate. Therefore, PRE-emergence herbicides should be used in combination with other modes of action, and integrated with other weed management approaches (e.g. cultural practices) to slow the evolution of resistance. 
Although the benefits of adopting integrated weed management approaches may not be as immediate, it can definitely have an impact on the soil weed seed bank and delay the evolution of weed resistance. This illustrates further that integrated weed control methods must be employed for successful long-term weed management (Schwartz-Lazaro and Copes, 2019).

\section{REFERENCES}

Boerboom, C., Owen, M.: The Glyphosate, Weeds, and Crops Series. The Glyphosate, Weeds and Crop Series, 1, $1-8,2006$.

Clayton, G. W., Harker, K. N., O'Donovan, J. T., Baig, M. N., Kidnie, M. J.: Glyphosate timing and tillage system effects on glyphosate-resistant canola (Brassica napus L.). Weed Technology, 16, 124-130, 2002.

Heap, I., Duke, S. O.: Overview of glyphosate-resistant weeds worldwide. Pest Management Science, 74, 1040 1049, 2018.

Knezevic, Z. S., Datta, A.: The Critical Period for Weed Control: Revisiting Data Analysis. Weed Science, 63 (1), 188-202, 2015.

Knezevic, Z. S., Evans, P. S., Blankenship, E. E., Van Acker, C. R., Lindquist, L. J.: Critical Period for Weed Control: The concept and data analysis. Weed Science, 50, 773-786, 2002.

Knezevic, Z. S., Pavlovic, P., Osipitan, O. A., Barnes, E. R., Beiermann, C., Oliveira, M. C., Lawrence, N., Scott, J. E., Jhala, A.: Critical Time for Weed Removal in glyphosate-resistant soybean as influenced by preemergence herbicides. Weed Technology, 33, 393-399, 2019.

Knezevic, Z. S, Streibig, J. C., Ritz, C.: Utilizing R Software Package for Dose-Response Studies: The Concept and Data Analysis. Weed Technology, 21, 840-848, 2007.

Hall, R. M., Swanton, J. C., Anderson, W. G.: The Critical Period of Weed Control in grain corn (Zea mays L.). Weed Science, 40 (3), 441-447, 1992.

Mulugeta, D., Chris, M. B.: Critical Time of Weed Removal in glyphosate-resistant soybean (Glycine max L.). Weed Science, 48 (1), 35-42, 2000.

Schwartz-Lazaro, L. M., Copes, J. T.: A review of the soil seedbank from a weed scientists perspective. Agronomy, 9 (7), 369, 2019.

Van Acker, R. C., Swanton, C. J., Weise, S. F.: The critical period of weed control in soybean (Glycine max L.). Weed Science, 41, 194-200, 1993.

\section{Uticaj pre-em primene herbicida na kritično vreme suzbijanja korova u soji tolerantnoj na dikambu}

\section{REZIME}

Ogled je sproveden 2019. godine u Haskell Agricalture Laboratory, Concord, NE, USA. Cilj ogleda bio je da se utvrdi uticaj PRE-EM herbicida na kritičan momenat suzbijanja korova u usevu soje tolerantne na dikambu. Ogled je postavljen kao potpuno slučajan blok sistem sa 28 tretmana (4 herbicidna tretmana sa 7 različitih vremena uklanjanja korova) u 4 ponavljanja. Primenjeni herbicidni tretmani su: (1) glifosat POST-EM, (2) acetohlor i dikamba PRE-EM i glifosat POSTEM, (3) acetohlor i dikamba PRE-EM i glifosat i dikamba POST-EM i (4) acetohlor i fomesafen kao PRE-EM i acetohlor, glifosat i dikamba kao POST-EM. Korovi su uklanjani kada je soja bila u fazama: V1, V3, V6, R2 i R5, a pored njih su postojale kontrole sa korovima i kontrole na kojima 
su korovi uklanjani tokom čitave vegetacione sezone. Primenom tretmana (2, 3 i 4) kritični momenat suzbijanja korova je bio pomeren za 632, 861 i 1060 SAT (suma aktivnih temperatura vazduha), tj. do V4, V6 i R1 faze razvoja soje, odnosno 28, 32 i 42 dana nakon nicanja.

Ključne reči: PRE-EM herbicidi, kritično vreme suzbijanja korova, rezistentnost na glifosat, integralno suzbijanje korova. 